\title{
Leadership Trends in Academic Libraries in Kenya
}

\author{
Justus Onkware Arita ${ }^{1, *}$, Victoria Munyao ${ }^{1}$, Marc Felix Mugoh Muriuki ${ }^{2}$, Benard Omallah George ${ }^{1}$ \\ ${ }^{1}$ Library Department, Mount Kenya University, Kenya \\ ${ }^{2}$ Systems Librarian, Kabarak University, Kenya
}

Copyright $\odot 2016$ by authors, all rights reserved. Authors agree that this article remains permanently open access under the terms of the Creative Commons Attribution License 4.0 International License.

\begin{abstract}
Succession planning enables internal people with the potential, to develop and fill key leadership positions in the library. This study sought to understand how academic libraries apply succession plan in their management. In this paper the researchers identified and discussed various succession planning strategies that exist in academic libraries, analyzed the benefits they accrue to their respective libraries and the challenges faced by library management in implementing the succession plan strategies. Through random sampling technique the researchers sampled various senior university staff from 5 academic libraries in Kenya. Questionnaires and focus group discussions were used to collect.
\end{abstract}

Keywords Leadership, Succession Planning and Academic Libraries

\section{Introduction}

Succession planning according to (Rothwell, 2010) is anticipating change in management, creating strategic plan to identify potential staff members, determining the gap in their knowledge, providing training, coaching, special assignments and experience so that they are ready to step up when the time comes. This strategy is widely in practice in large private companies but has not been taken up by librarians. Kenya Commercial Bank identified an insider, Joshua Oigara to take over as CEO following the expiry of Martin Oduor-Otieno tenure, Martin Oduor Otieno had himself been tapped from within $\mathrm{KCB}$ to replace then $\mathrm{CEO}$ Terry Davidson in May, 2007; Kenya Airways has already identified Mbuvi Ngunze to take over after the expiry of current CEO Titus Naikuni tenure. This shows well established succession planning program within some organizations.

Just as it happens in private companies libraries in Kenya too have experienced situations where the librarian or someone in the management has had to leave for one reason or another. In the recent, years we have had University librarian vacancies in most of the libraries like Kenya
Methodist University, Kenyatta University Library, United States International University-Africa, Pwani University, Maseno University, Strathmore University just to mention but a few. Lack of well elaborate succession planning structures within the library makes it difficult for University Human resource to tap insiders to fill the vacant position in University library from within the pre-existing library staff.

There are however signs of uptake of succession planning within the library as demonstrated by our research and we hope that with the sensitization of the importance of succession planning in academic libraries through workshops such as Kenya Library Association annual workshop, the uptake will increase even more. Of note is the Strathmore University scenario where the deputy university librarian took over after the departure of the then university librarian.

\section{Literature Review}

There is not much research on succession planning in libraries leave alone succession planning in academic libraries. Notable however is (P. Singer, Goodrich, \& Goldberg, 2004) which describes how Multnomah County library in Portland, Oregon developed to prepare and train younger librarians for the anticipated upper level vacancies. This article published in the 'Library Journal' also gives a brief outline how to set up a succession plan program through what the authors call a 'Succession Planning Tool Kit'. Similarly (Nixon, 2008) outlines the basic steps of succession planning. Both papers agree that for succession planning to work, there must be support from top-level management.

Libraries without internal human resources department, which is the case in most academic libraries; the library management must work together with the human resource department of the institution. Succession planning hence is not just about senior librarians grooming and mentoring staff reporting to them. The human resources department has to be deeply involved and so does library staff members. There also has to exist open communication that allows identified librarians with the potential to fill upper level positions to receive feedback about their strength and areas 
they need to work on, to effectively position themselves to take up more senior positions.

\section{Research Methodology}

This paper utilizes action research methodology to solve the immediate problem facing academic libraries whenever a key staff leaves the library. This research used questionnaire as the primary data collection technique and focus group discussions.

Random sampling was used to select 25 library staff out of a target population of 100 staff from 5 academic libraries in Kenya. Online questionnaires were sent to 20 librarians from 4 universities while in one university library focus group discussions were used to collect data.

Survey Monkey, an online survey tool was used to collect and tabulate data.

\section{Research Findings}

This research found that most academic libraries do not have a succession plan in place. The graph below illustrates statistical data collection from various academic libraries.

Table 1. Succession Planning Policy in Organization

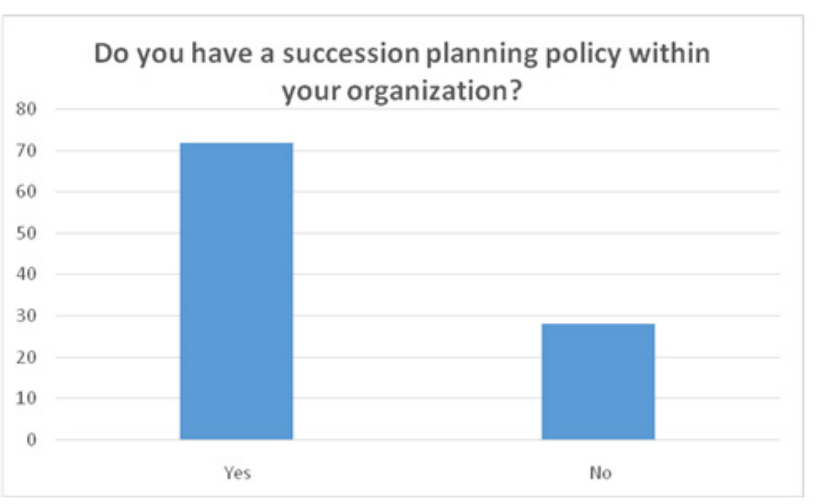

The sampled staff also reported having benefited from staff training and development without necessarily getting the promotions when they arise. Similarly librarians reported having benefitted from internal promotion without there being a succession planning program in place.

In (P. M. Singer, 2010) words succession planning in library leadership has profound benefit to the entire organization. This paper found out the following as some of the benefits a library is bound to gain from well implemented succession planning program.

- It facilitates in-house replacement/Promotions

- Increased human capital

- Boost employee morale

- It helps avoid lost productivity

- Its creates career opportunities

- Enables the library to retain key talent

- It enable the library to attract talent

- It helps the library prepare for future challenges
- It facilitates knowledge transfer

- It controls hiring cost

- It saves time while hiring

- It facilitates staff training and development through workshop facilitation, paid academic leave and education sponsorship.

- It increases career advancement opportunities for staff

\subsection{Challenges Encountered While Implementing Succession Planning in Academic Libraries}

- $\quad$ Lack of qualified in-house staff

- Balancing the aspirations of the staff with those of the library

- Lack of clearly defined policy on succession planning

- Most libraries lack enough staff members to mentor and train new leaders

- Higher education institutions are actively working to increase diversity; every opening is an opportunity.

\section{Recommendations}

This paper recommends that universities adopt a succession planning program to limit the negative effect including key staff members such as University librarians, Systems librarian among others resign from libraries. The paper goes ahead and develops a 6 step guide to establish the program.

\subsection{Succession Planning Tool Kit for Academic Libraries}

Different authors have various steps on how to develop a succession planning program. This paper has identified steps that an academic library would take to come up with a viable succession planning program.

\section{i. Formulate a library committee}

This committee will be in charge with implementing the succession planning program. It will compose of the University Librarian, Human Resource Director, DVC Administration, DVC Finance and an external human resources consultant.

\section{ii. Determine the library strategic Direction}

This involves identifying the current and future priorities of the library. This will facilitate the development of talents needed to offer future services.

iii. Identify critical positions and high potential employees

This requires the committee to identify essential positions within the library and then come up with a list of library staff within potential to take up those positions. This step also involves developing a list of skills, abilities and experience of the next generation library leaders. 


\section{iv. Assess candidates' Strength and weaknesses}

This involves the library committee interviewing all the potential candidates to identify the skills, competencies, experience and interests. A candidate could have extensive referencing skills but lack competencies such as decision making or managing conflict. During this step a gap analysis is conducted to determine the skillset of the employee against the expected skillset.

\section{v. Develop a training program to build competencies}

The potential candidates will need care and cultivation to a mass the skills still needed to get to the expected skill range. It is important to develop several high potential candidates in tandem as the first choice candidate can always be enticed by another employer. A lead time of about 2 years would be ideal.

While training is an important strategy to build competencies for better results it should be coupled with other strategies such as On-the-job coaching and Rotation of assignments.

Given that most potential candidates are librarians by training and have little or no management training the candidates should also be trained on management skills such as how to achieve goals, motivate staff, mentor staff, prepare budgets, staff selection, crises management, evaluation, donor relations, manage buildings, maximize employee potential etc.

According to (Ibarra, 2005) a variety of resources are available to enable employee to bridge the gap and build stronger competencies. These resources are illustrated in the figure below:

Table 2. Employment Development Strategy

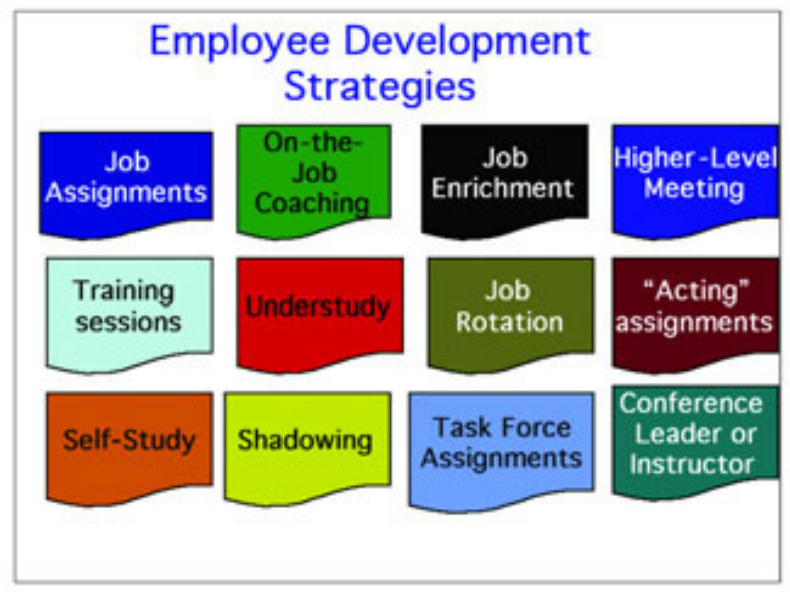

\section{Monitor and Evaluate}

The library committee should constantly review the progress of the candidates informing them of their gaps and how the specific opportunities are supposed to help them bridge the gap. This allows them to encourage and motivate those candidates who are not meeting expectations and at the same time provide more challenging opportunities to those who meet their targets.

This is a continuous process hence ensuring that staffs are always available to fill up opportunities that may fall vacant either abruptly as in the case of death, pursuit of greener pastures, or gradually as in the case of retirement.

\section{Conclusions}

The study concluded that most libraries do have succession plan strategies such as in-house promotion and staff training but have no elaborate succession planning policy document. As a result succession planning program will not burden the library budget but will instead create well defined structures for human resource development.

Finally implementation of a succession planning program shows how much we value our stakeholders that rely upon the library for education, research, enjoyment and personal enrichment.

\section{REFERENCES}

[1] Ibarra, P. (2005). Succession Planning. Public Management. Retrieved from http://mejorandogroup.com/assets/IbarraSuc Planning.pdf

[2] Nixon, J. M. (2008). Growing your own leaders: succession planning in libraries. Journal of Business \& Finance Librarianship, 13(3), 249-260.

[3] Rothwell, W. J. (2010). Effective succession planning: Ensuring leadership continuity and building talent from within. AMACOM Div American Mgmt Assn.

[4] Singer, P., Goodrich, J., \& Goldberg, L. (2004). Your Library's Future: When Leaders Leave, Succession Planning Can Smooth the Transitions. Library Journal, 129(17), 38.

[5] Singer, P. M. (2010). Succession planning in the library: Developing leaders, managing change. American Library Association. 